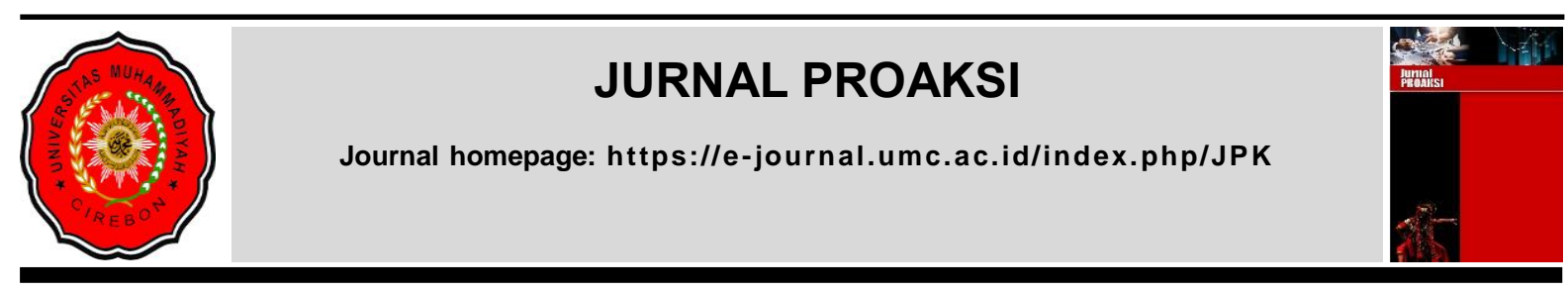

\title{
EVALUASI PELAKSANAAN PROBITY AUDIT DALAM RANGKA AKUNTABILITAS PENGELOLAAN DANA SEKTOR PUBLIK
}

\author{
Dharu Wicaksono ${ }^{1}$ \\ Gideon Setyo Budiwitjaksono ${ }^{2 *}$ \\ ${ }^{1}$ Fakultas Ekonomi dan Bisnis Universitas Pembangunan Nasional "Veteran" Jawa Timur \\ Email : dharu1605@gmail.com \\ ${ }^{2}$ Fakultas Ekonomi dan Bisnis Universitas Pembangunan Nasional "Veteran" Jawa Timur \\ *Corresponden Author Email : gideon.ak@ upnjatim.ac.id
}

Diterima : 21 Juli 2021

Direvisi : 2 Agustus 2021

Dipublikasikan : 17 Oktober 2021

\begin{abstract}
Abstrak
This research is aimed at conducting "Evaluationof The Implementation of Probity Audit in the frameworkof Accountability of Public Sector Fund Management" against Government Agencies that have obligations and tupoksi to conduct probity audits. Methods applied in the discussion apply qualitative methods through the application of inpretive phenomenology. It is used by researchers in order to explore an individual's understanding of his environment and also to understand a person's perspective on a personal experience, especially related to the implementation of probity audits, especially those conducted by the Mojokerto City Inspectorate. The results that can be concludedare about the Probity Audit of procurement of goods and services carried out by the Mojokerto City Inspectorate so far is considered to still require a number of improvements seen from the three stages in the implementation of Probity Audit conducted, namely Planning, Implementation and Utilization of its Report. But the effectiveness of Probity Audit on the procurement of goods and services is considered very effective against public sector fund management accountability in view of the willingness and high awareness from the auditorship of the Mojokerto City Inspectorate and Local Government Organizations (OPD) for the benefits of Goods and Services audit probity activities that have until now been obtained.
\end{abstract}

Keywords: Accountability, Procurement of Goods and Services, Probity Audit

\section{PENDAHULUAN}

Pengaturan dalam keuangan daerah dengan cara yang benar bisa menyajikan gambaran terhadap kesuksesan maupun efektivitas dari program kegiatan oleh sebuah organisasi pemerintah. Darwanis (2016), menjelaskan bagaimana suatu pengaturan keuangan yang tepat serta efektif merupakan bentuk penerapan "tata kelola pemerintahan yang baik (good governance)". Mardiasmo (2009), juga menyebutkan adanya 3 (tiga) ciri-ciri khusus dalam penerapan good governance yang bisa digunakan oleh pemerintah daerah yakni "penciptaan transparasi, akuntabilitas publik, dan value for money (economy, efficiency dan effectiveness)". Tiga ciri-ciri khusus tersebut memiliki hubungan serta saling mendukung dalam pembentukan konsep good governance.

Di Indonesia praktek kecurangan ( $\mathrm{fraud}$ ) dalam pengelolaan keuangan daerah dirasakan masih sangat sering terjadi, salah satunya dalam pelaksanaan Pengadaan Barang dan Jasa. Berdasarkan berita yang dikutip melalui detik.com (Hariyanto, 2020), Wakil Ketua KPK Nawawi Pomolango menyampaikan bahwa atas kasus korupsi yang telah ditangani KPK sekitar $70 \%$ berasal dari proses pengadaan barang dan jasa. Bahkan menurutnya, mengenai kasus korupsi disertai modus operandi berupa suap, juga berawal dari proses pengadaan barang dan jasa. Purwanto dalam Mulyono (2017), menjelaskan secara konvensional permasalahan yang ditemui pada pelaksanaan kegiatan pengadaan 
barang/jasa bisa dikelompokkan menjadi permasalahan berikut ini: (1) kurangnya pemantauan (monitoring); (2) adanya penyelewengan wewenang; (3) penyelewengan dalam kontrak; (4) kolusi dari pihak pejabat publik dengan rekanannya; (6) adanya perubahan data serta kurangnya transparansi; (7) SDM yang tidak kompeten dan berintegritas.

Salah satu upaya pemerintah dalam mencegah korupsi pada pelaksanaan pengadaan barang/jasa, yakni melalui penerapan "audit pengadaan barang dan jasa secara real-time" atau dapat dikatakan sebagai "probity audit". Hal itu didukung dengan penelitian lain yang juga menunjukkan bagaimana Probity Audit merupakan bentuk penerapan metode yang sangat tepat untuk dapat menghindari serta meminimalisir munculnya fraud (Detkova dkk., 2018). Di Indonesia pelaksanaan Probity Audit didasari oleh "Peraturan Kepala Badan Pengawasan Keuangan dan Pembangunan Nomor: PER-362/K/D4/2012 tentang Pedoman Probity Audit Pengadaan Barang/Jasa Pemerintah Bagi Aparat Pengawasan Intern Pemerintah (APIP)". Probity Audit merupakan satu cara guna menambah peran dan fungsi dari APIP pada saat penerapan kegiatan observasi yaitu dengan melakukan audit pada saat proses pengadaan barang/jasa.

Probity Audit pada umumnya diterapkan terhadap suatu kegiatan yang sifatnya strategis yang berkaitan dengan sejumlah kepentingan masyarakat, pelayanan umum serta yang berhubungan terhadap permasalahan politik. Adapun teknik Probity Audit yang seringkali digunakan yaitu melalui pemeriksaan secara langsung, pengawasan, komunikasi serta wawancara namun juga tidak melupakan metode dalam audit yang lain. Hasil yang diharapkan dengan adanya proses pengadaan barang/jasa yang didasari oleh prinsip probity yaitu untuk mengurangi munculnya perselisihan serta permasalahan, mengantisipasi terjadinya tindakan fraud, untuk dapat meyakinkan dengan cara yang objektif serta independen terhadap kejujuran (probity) proses pengadaan barang/jasa, selain itu juga untuk mengurangi munculnya permasalahan hukum/litigasi (BPKP, 2012).

Penelitian sebelumnya dari Ramadhan dan Arifin (2019), memperlihatkan bagaimana penerapan Probity Audit oleh Inspektorat Provinsi DKI Jakarta dalam mengimplementasikan Probity Audit belum optimal karena penerapannya tidak diberlakukan kepada seluruh proses yang ada dalam pedoman probity audit. Penelitian Diawati (2017), memperlihatkan bagaimana penerapan Probity Audit di Inspektorat Kabupaten Sleman memperlihatkan temuan yang cukup memuaskan namun tetap saja belum diterapkan secara optimal. Atas dasar hasil penelitian-penelian tersebut serta masih maraknya temuan permasalahan korupsi pengadaan barang/jasa oleh pemerintah yang sedang terjadi di Indonesia, peneliti menjadi tertarik untuk menganalisa keefektifan pelaksanaan pengadaan barang dan jasa di dalam Inspektorat Kota Mojokerto yang ditujukan untuk mendukung terwujudnya akuntabilitas pengaturan pada keuangan sektor publik yang didasari oleh adanya penerapan Probity Audit yang sudah dilakukannya. Topik ini dapat memberikan manfaat bagi akademisi dan praktisi untuk memberikan tambahan pengayaan informasi terkait pentingnya kegiatan serta atantangan yang dihadapi dalam pelaksanaan probity audit.

\section{KAJIAN PUSTAKA}

\section{Role Theory (Teori Peran)}

"Teori peran (role theory)" dijelaskan oleh Kahn dkk. (1964). Berdasarkan Kahn dkk. (1964), teori peran adalah pembatasan terhadap perilaku individu sebagai anggota masyarakat yang mengadaptasi perilaku mereka agar sesuai terhadap posisi yang dimiliki dalam lingkungan sosialnya. Dalam penelitian ini, yang dimaksud peran adalah peranan dari Inspektorat di Pemerintahan Kota Mojokerto yang dibuat oleh pemerintah dan mempunyai fungsi untuk menjadi auditor internal. "Aparat Pengawasan Internal Pemerintah (APIP)" wajib untuk memberikan peran serta kontribusi agar dapat menghasilkan tata kelola pemerintahan secara tepat serta transparan. Dalam penelitian Alzeban dan Sawan (2013), Audit Internal juga harus berperan sebagai manajemen risiko untuk meminimalisir adanya risiko kecurangan ( fraud).

\section{Audit Sektor Publik}

Definisi “Audit Sektor Publik" berdasarkan Rai (2008), merupakan kegiatan suatu lembaga yang dapat memberikan bantuan terhadap penyediaan barang dimana biaya yang digunakan bersumber dari pemasukan pajak serta sumber penerimaan negara yang lain dan ditujukan agar bisa membandingkan antara fakta keadaan yang terjadi terhadap penilaian yang digunakan. Fungsi dari pelaksanaan audit sektor publik yaitu supaya dapat memberi jaminan telah diterapkannya bentuk 
tanggungjawab sosial yang sudah dilakukan pemerintah, termasuk juga dari pemerintah pusat hingga pemerintah daerah, selain itu juga untuk dapat membentuk pemerintahan yang transparan serta terbebas dari tindakan korupsi, kolusi, dan nepotisme (BPK RI, 2017). Mendukung pernyataan tersebut penelitian Raharjo dan Mahyuni (2019), juga menjelaskan bahwa pengaturan dana pemasukan pemerintahan yang tepat dan efektif wajib diiringi dengan pelaksaanan audit sektor publik dengan kualitas yang baik sebab apabila kualitas audit sektor publik berkurang, maka dapat berdampak pada munculnya risiko tuntutan hukum (legitimasi) kepada setiap pegawai pemerintah yang bertugas.

\section{Auditor Internal Pemerintah}

"Auditor internal Pemerintah" atau yang biasa disebut sebagai "Aparat Pengawasan Intern Pemerintah (APIP)". Di Indonesia, lembaga pemerintah yang memiliki peran dalam pelaksanaan pengawasan internal pada kegiatan pemerintah pusat maupun pemerintah daerah yaitu antara lain "Badan Pengawasan Keuangan dan Pembangunan (BPKP), Inspektorat Jenderal/Inspektorat/Unit Pengawasan Intern pada Kementerian, Inspektorat Utama/Inspektorat Lembaga Pemerintah NonKementerian, Inspektorat/Unit Pengawasan Intern pada Kesekretariatan Lembaga Tinggi Negara dan Lembaga Negara, Inspektorat Provinsi/Kabupaten/Kota, dan Unit Pengawasan Intern pada Badan Hukum Pemerintah lainnya sesuai dengan peraturan perundang-undangan”. Lembaga auditor internal tersebut, memiliki fungsi untuk melakukan pencegahan tindakan fraud terhadap seluruh lembaga pemerintahan untuk mewujudkan tata kelola pemerintahan yang baik. Sebagai auditor internal mereka diwajibkan untuk melakukan pengecekan serta observasi terhadap diterapkannya sebuah kebijakan dari pemerintah pusat dan juga dari daerah serta kemudian melaporkan hasil pemeriksaan tersebut sesuai dengan realita yang terjadi.

\section{Pengadaan Barang dan Jasa Pemerintah}

"Pengadaan barang dan jasa pemerintah" telah disebutkan hukumnya pada "Peraturan Presiden Republik Indonesia Nomor 16 tahun 2018", dimana pasal 1 dalam peraturan tersebut menjelaskan "Pengadaan Barang/Jasa adalah kegiatan untuk memperoleh Barang/Jasa oleh Kementerian/Lembaga/Satuan Kerja Perangkat Daerah/Institusi yang prosesnya dimulai dari perencanaan kebutuhan sampai diselesaikannya seluruh kegiatan untuk memperoleh Barang/ Jasa". Berdasarkan penelitian Faisal dkk. (2017), terdapat prinsip-prinsip dasar yang harus dipenuhi dalam suatu proses pelaksanaan pengadaan barang dan jasa dan diatur dalam "Peraturan Presiden Republik Indonesia Nomor 54 Tahun 2010 tentang pengadaan Barang dan Jasa Pemerintah", yakni antara lain Efisiensi, Efektivitas, Transparansi, Keterbukaan, Saling Bersaing, Berdasarkan Asas Keadilan serta Akuntabilitas.

\section{Praktik Penyimpangan pada Pengadaan Barang dan Jasa Pemerintah}

Mayoritas di Indonesia pengeluaran belanja Negara yang besar digunakan untuk kegiatan pengadaan barang dan jasa. Keadaan tersebut sangat berimplikasi dengan risiko penyimpangan pada pengadaan barang/jasa. Menurut Arsyad dkk. (2016), menyatakan bahwa pada saat pelaksanaan pengadaan barang dan jasa memiliki sisi negatif yang umumnya dapat muncul dalam bentuk proses tender tidak transparan, suap untuk memenangkan tender, adanya kolusi, serta spesifikasi teknik mengarah pada suatu merk tertentu supaya bisa untuk dimanipulasi oleh satu pihak badan usaha tertentu. Menurut Mulyono (2017), secara konvensional penyebab munculnya persoalan pada saat proses pengadaan barang dan jasa diantaranya didorong oleh sejumlah faktor yakni, Minimnya pengawasan; Penyelewengan wewenang; Penyelewengan dalam kontrak; Kolusi dari pihak pejabat publik dengan rekanannya; Adanya perubahan data serta kurangnya transparansi; SDM yang tidak kompeten dan berintegritas.

\section{Probity Audit atas Pengadaan Barang dan Jasa}

Seperti yang telah dijelaskan dalam "Peraturan Pemerintah Nomor 60 tahun 2008 pasal 59 terkait Sistem Pengendalian Intern Pemerintah (SPIP) dalam proses pengadaan barang/jasa", BPKP merupakan lembaga yang diberi amanah untuk menerapkan pengawasan terhadap pelaksanaan "pemerintahan yang baik (good governance)". Salah satunya dengan upaya menambah fungsi dari APIP dalam penerapan observasi terkait pelaksanaan audit pada saat kegiatan pengadaan barang/jasa berlangsung (realtime) yang biasa dikenal sebagai probity audit. Oleh karena itu BPKP mengeluarkan pedoman pelaksanaan Probity Audit yang disebutkan pada "Peraturan Kepala Badan Pengawasan Keuangan dan Pembangunan No. PER-362/K/D4/2012 tentang Pedoman Probity Audit Pengadaan 
Barang/Jasa Pemerintah Bagi Aparat Pengawasan Intem Pemerintah (APIP)". Probity Audit wajib untuk dilaksanakan berdasarkan pada prinsip probity yang dapat disimpulkan sebagai prinsip-prinsip pengadaan barang/jasa dan telah diatur dalam "Perpres 54 tahun 2010" yakni antara lain Efisiensi, Efektivitas, Transparansi, Keterbukaan, Saling Bersaing, Berdasarkan Asas Keadilan serta Akuntabilitas. Dimana tujuan dari pelaksanaan prinsip-prinsip probity tersebut yaitu supaya dapat "Menghindari permasalahan, Menghindari praktek korupsi, Meningkatkan integritas sektor publik, Memberi keyakinan kepada masyarakat atas penyelenggaraan kegiatan sektor publik yang dapat dipercaya, Memberikan keyakinan secara atas kejujuran (probity) proses pengadaan barang/jasa, Meminimalkan litigasi (permasalahan hukum)".

\begin{abstract}
Akuntabilitas Pengelolaan Dana Sektor Publik
Pengertian akuntabilitas menurut Mardiasmo dalam Jitmau dkk. (2017), menjelaskan bahwa "akuntabilitas publik" adalah tanggungjawab dari pihak yang "memegang amanah (agent)" dan dituntut untuk dapat menyediakan sebuah bentuk tanggungjawab, penyajian data, laporan, serta hasil audit dari seluruh pelaksanaan kegiatan yang termasuk kedalam wewenangnya terhadap pihak yang "memberikan amanah (principal)" yang mempunyai hak serta wewenang dalam menuntut hasil dari tanggungjawab tersebut. Akuntabilitas dapat dikelompokkan ke dalam dua kelompok yakni "(1) akuntabilitas vertikal (vertical accountability) dan (2) akuntabilitas horizontal (horizontal accountability)". Sehingga dengan meningkatnya ukuran dari "akuntabilitas pengelolaan keuangan daerah" maka juga dapat meningkatkan tingkat kepercayaan masyarakat kepada pemerintah (Nurrizkiana dkk., 2017). Lembaga Administrasi Negara dalam Novitaningrum (2014), menjelaskan adanya penilaian karakteristik yang bisa digunakan untuk memahami seberapa baik tingkat penerapan dari prinsip akuntabilitas yaitu antara lain, Akuntabilitas pengaturan keuangan yang dilaporkan; Bentuk tanggungjawab dari performa yang dihasilkan; Tingkat terjadinya fraud; serta Upaya untuk mengurangi tingkat fraud. Berlandaskan "Peraturan Presiden nomor 54 tahun 2010 tentang pengadaan barang dan jasa pemerintah", menjelaskan bahwa Probity Audit adalah aktivitas pengecekan (independen) guna menjamin bahwa kegiatan yang dilaksanakan sudah berdasarkan pada peraturan undang-undang yang ditetapkan serta ditujukan guna menambah nilai akuntabilitas dari pemakaian keuangan sektor publik yang nantinya bisa untuk dilaporkan sebagai bentuk tanggungjawab (BPKP, 2012) .
\end{abstract}

\title{
METODOLOGI PENELITIAN
}

Jenis Penelitian ini menerapkan bentuk "penelitian kualitatif" dan disertai "pendekatan fenomenologi intepretif". Hasil yang ingin dicapai dalam penelitian ini yakni agar dapat memahami kesesuaian atas "pelaksanaan Probity Audit pengadaan barang dan jasa dengan pedoman Probity Audit", selain itu juga untuk mengetahui kendala serta upaya yang dihadapi oleh Inspektorat Kota Mojokerto dalam rangka terwujudnya akuntabilitas dana sektor publik, di dalam penelitian ini peneliti menggunakan pendekatan Fenomenologi Interpretif. Penelitian ini difokuskan pada "Pelaksanaan Audit atas pengadaan barang dan jasa yang dilakukan oleh Inspektorat Kota Mojokerto" berdasarkan dokumen rekapitulasi atas kegiatan pelaksanaan probity audit.

Jenis data yang diterapkan pada penelitian ini merupakan "jenis data kualitatif dan data kuantitatif". Sumber data yang diterapkan pada penelitian ini merupakan "sumber data primer dan data sekunder". Data primer didapatkan dengan melakukan wawancara secara langsung dari pihak peneliti terhadap pihak Inspektorat Kota Mojokerto, yaitu Auditor yang melaksanakan audit terhadap kegiatan Pengadaan Barang dan Jasa dan juga harus mempunyai pengetahuan tentang pelaksanaan Probity Audit yang ada di Inspektorat Kota Mojokerto. Sementara data sekunder berupa laporan audit terdahulu dan dokumen-dokumen yang menjadi bukti pendukung dari Inspektorat Kota Mojokerto.

Teknik pengumpulan data yang diterapkan oleh peneliti yaitu antara lain menggunakan metode Observasi secara pasif melalui cara pengumpulan data dengan cara bertemu secara langsung dengan objek penelitian namun tidak terlibat dalam aktivitasnya. Selain itu juga melalui wawancara dengan subjek penelitian, studi pustaka dengan menghimpun bahan pustaka yang relevan terhadap penelitian, dan juga studi dokumentasi berupa catatan pribadi dari subjek penelitian. Kemudian peneliti juga menggunakan alat bantu penelitian berupa alat perekam, kamera, alat tulis, handphone, daftar pertanyaan wawancara, buku, jumal, serta referensi yang lain. 


\section{Teknik Analisis}

Penelitian ini menggunakan dua teknik triangulasi yakni "triangulasi sumber data dan triangulasi teori". "Triangulasi Sumber Data", yaitu upaya untuk mencari kebenaran informasi yang spesifik dengan mencarinya pada sejumlah sumber data yang dapat diperoleh. Dimana langkah-langkah yang dapat diterapkan adalah seperti dengan cara membuat perbandingan "data hasil pengamatan (observasi)" terhadap "data hasil wawancara", membuat perbandingan antara pernyataan yang disebutkan oleh individu lainnya terkait fokus dari penelitian terhadap pernyataan yang telah disebutkan oleh informan selama periode penelitian terjadi, membuat perbandingan antara kondisi serta sudut pandang dari seorang individu terhadap sejumlah pernyataan serta sudut pandang dari individu lainnya maupun dari kelompok lain. Sementara "Triangulasi teori" yaitu merupakan penggabungan dua teori atau lebih yang nantinya akan saling dibandingkan serta digabungkan antara satu sama lain dan juga membuat perbandingan dari hasil wawancara yang didapat dari narasumber melalui pendekatan sejumlah teori yang dapat digunakan serta relevan terhadap topik dari penelitian ini yang nantinya diharapkan dapat menghasilkan sebuah temuan penelitian kualitatif yang dapat berupa sebuah rumusan informasi atau thesis statement. Sehingga dibutuhkan suatu perencanaan penelitian, pengumpulan data, serta analisa data yang komprehensif, dan diharapkan nantinya bisa menyajikan hasil yang juga semakin komprehensif.

\section{Pengujian Data}

Proses pengujian data yang dilaksanakan dapat diuraikan ke dalam beberapa tahapan antara lain, 1) Peneliti mengelompokkan seluruh data yang telah dikumpulkan. 2) Menganalisa keseluruhan data yang dikumpulkan serta mengelompokkan data-data tersebut. 3) Mengelompokkan pernyataan dari informan. 4) Melakukan reduksi data. 5) Penyajian data menggunakan metode interpretatif. 6) Membuat suatu kesimpulan penelitian. Berdasarkan pengumpulan data serta hasil analisis data yang sudah diterapkan, peneliti kemudian mensintesakannya untuk menemukan makna dari seluruh fenomena yang telah didapatkan dan menuliskan keterbatasan-keterbartasan yang telah dihadapi dalam penelitian ini serta mendeskripsikan kendala, saran maupun rekomendasi dari hasil yang didapatkan pada penelitian ini.

\section{HASIL DAN PEMBAHASAN}

\section{Deskripsi Penelitian}

\section{Gambaran Umum Inspektorat Kota Mojokerto}

Pembentukan dari Inspektorat didasari oleh "peraturan pemerintah tentang Pedoman organisasi perangkat daerah dan peraturan tentang pedoman menteri dalam negeri nomer 64 tahun 2007 tentang pedoman teknis organisasi dan tata kerja Inspektorat provinsi dan kabupaten/kota". Selain itu juga berdasarkan pada "Peraturan daerah Kota Mojokerto nomor 5 tahun 2008 tentang organisasi lembaga teknis Kota Mojokerto", inspektorat adalah lembaga daerah yang menjadi unsur penunjang bagi pemerintah kota mojokerto untuk dapat melaksanakan tugas pemerintahan daerah serta pengaturan bidang pembangunan dan tugas dari lembaga tersebut adalah mengawasi pelaksanaannya.

\section{Struktur Organisasi}

"Susunan organisasi Inspektorat Kota Mojokerto" didasari oleh "Peraturan Walikota Mojokerto Nomor 97 Tahun 2020, tentang Kedudukan, Susunan Organisasi, Tugas dan Fungsi Serta Tata Kerja Inspektorat Kota Mojokerto pasal 3" yang menyebutkan mengenai Inspektorat Kota Mojokerto memiliki tugas dalam mengawasi penerapan seluruh kegiatan pemerintahan dalam wilayah pemerintah daerah. Jumlah Personil Inspektorat Kota Mojokerto sebanyak 27 orang. Obyek Pengawasan pada tahun 2021 dari seluruh satuan kerja lingkup Pemerintah Kota Mojokerto yaitu Dinas, Badan, Sekretariat DPRD dan Kecamatan dengan perincian sebanyak 25 anggota. Dari obyek pengawasan tersebut akan dilakukan pengawasan hanya pada Satuan Kerja Perangkat Daerah yang memiliki risiko tinggi saja, agar hasil pengawasan lebih efisien dan efektif.

\section{Pelaksanaan Audit Pengadaan Barang dan Jasa yang Bersifat Probity Audit oleh Inspektorat Kota Mojokerto}

"Audit Pengadaan Barang dan Jasa Pemerintah (APBJ)" merupakan proses audit yang ditujukan untuk kebutuhan tertentu, ("Undang-Undang No. 15 Tahun 2004 tentang Pemeriksaan Pengelolaan dan Tanggung Jawab Keuangan Negara Pasal 4 ayat 4"), yang termasuk kedalam proses 
audit terhadap sistem pengendalian internal pemerintah. "Peraturan Presiden Republik Indonesia Nomor 16 Tahun 2018 tentang Pengadaan Barang/Jasa Pemerintah Pasal 76" menjelaskan bahwa seluruh Menteri/Kepala Lembaga/Kepala Daerah diharuskan untuk menerapkan Pengawasan Pengadaan Barang/Jasa yang dapat dilaksanakan oleh Aparat Pengawasan Internal terhadap Kementerian/Lembaga/Pemerintah Daerah masing-masing, melalui pelaksanaan proses audit, review, observasi, penilaian, serta pelaksanaan sistem whistleblowing mulai dari tahapan perencanaan kegiatan, mempersiapkan berbagai kebutuhan, seleksi terhadap penyedia, pemberian kontrak, serta hingga penyerahaan kontrak kerja. Salah satunya yakni melalui pelaksanaan audit terhadap seluruh tahapan proses pengadaan barang/jasa yang sedang berlangsung (real time) yang juga dikenal sebagai probity audit. Inspektorat Kota Mojokerto adalah bagian dari "Aparat Pengawasan Internal Pemerintah (APIP)" yang sudah menerapkan proses Probity Audit terhadap pengadaan barang dan jasa, namun tetap menjumpai sejumlah permasalahan dan memerlukan sejumlah perbaikan dalam setiap tahap pelaksanaannya.

Analisa atas Tahap Perencanaan kegiatan audit barang dan jasa khususnya Probity Audit oleh Inspektorat Kota Mojokerto, peneliti melakukan analisa atas Dokumen Program Kerja Pengawasan Tahunan (PKPT) Inspektorat Kota Mojokerto mulai tahun 2019 sampai dengan 2021 yang disahkan setiap tahunnya oleh Walikota Mojokerto. Dimana pada tahun 2019 dan 2020 direncanakan dalam setiap tahunnya oleh Inspektorat Kota Mojokerto namun tidak secara khusus menyatakan adanya kegiatan Audit Tujuan Tertentu sebagaimana sifat dari Probity Audit atas Pengadaan Barang dan Jasa. Tidak demikian pada tahun 2021, Audit Tujuan Tertentu telah diklasifikan secara rinci atas pelaksanaannya dan menyebutkan jenis audit berupa Probity Audit atas Pengadaan Barang dan Jasa, selain itu juga menjelaskan mengenai tahapan apa yang menjadi ruang lingkup pengawasan oleh Inspektorat Kota Mojokerto yang akan dilakukan pada satu tahun kedepan. Namun terdapat hal yang perlu diperhatikan adalah Probity Audit yang akan dilakukan masih terbatas pada salah satu tahapan misalnya perencanaan saja, pelaksanaannya saja ataupun pemanfaatannya saja. Atas hal tersebut peniliti menanyakan atas pelaksanaan Probity Audit yang selama ini telah diterapkan oleh Inspektorat Kota Mojokerto, wawancara dilakukan kepada Sdri. Rr. Intan Ari Budi Astuti, ST. MT pada tanggal 21 Mei 2021 menyatakan bahwa:

"Probity Audit ini seingat kami mulai dilaksanakan oleh Inspektorat Kota Mojokerto sekitar tahun 2018 dimana selama ini yang dilakukan oleh Inspektorat Kota Mojokerto mengacu pada Pedoman yang dikeluarkan oleh BPKP. Dimana kita memisahkan didalam pelaksanaanya membaginya dalam tiga tahapan, yaitu perencanaan, pemilihan pemenang dan pelaksanaan. Bisa dilihat pada PKPT kami bahwa untuk tahap Perencanaan dijadwalkan pada bulan Februari dan Maret. Hal ini didasarkan karena tujuan dari Probity Audit yang digunakan untuk mengawasi pengadaan pada terjadi (real time) serta sifatnya preventif menjaga agar tidak terjadinya penyimpangan sehingga harapannya hasil rekomendasi dari Probity Audit yang dilakukan pada awal tahun dapat ditindaklanjuti, dan mengurangi permasalahan pada tahap pelaksanaannya sampai dengan pemanfaatannya".

Analisa atas Tahap Pelaksanaan Probity Audit oleh Inspektorat Kota Mojokerto dalam "Ikhtisar Laporan Hasil Pengawasan Aparat Pengawasan Intern Pemerintah (APIP) Kota Mojokerto tahun 2019 dan 2020", diketahui bahwa dalam kebijakan pelaksanaan Probity Audit yang harus dibuat oleh Instansi Pengawasan pada masing-masing daerah, Inspektorat Kota Mojokerto pada saat pelaksanaan kegiatan Probity Audit atas pengadaan barang dan jasanya hingga kini masih belum memiliki kebijakan khusus yang mengatur pelaksanaan Probity Audit di Lingkungan Pemerintahan Kota Mojokerto sehingga pada implentasinya hanya merujuk pada Pedoman Probity yang dikeluarkan oleh BPKP. Selain itu tidak kalah pentingnya yakni dalam kebijakan kriteria spesifikasi auditornya dimana akan berguna untuk kualitas laporan yang dihasilkan karena auditor yang dimiliki Inspektorat Kota Mojokerto dalam melakukan Probity Audit telah memiliki kompetensi yang layak.

Berdasarkan wawancara yang dilakukan kepada Sdr. Drs. Leo Haposan, M.Si. pada tanggal 21 Mei 2021 terkait keberadaan kebijakan Probity Audit yang dikeluarkan oleh Kepala Daerah/Pimpinan Instansi dinyatakan bahwa: "Sepengatuhuan kami belum ada, kita sementara ini untuk pedoman Probity Audit hanya mengacu pada Pedoman BPKP Nomor PER-362/K/D4/2012. Sehingga terbatas pada mekanisme atau prosedur pelaksanaannya saja, diluar hal tersebut misalnya penentuan tingkat urgensi atas OPD mana yang harus dipilih untuk dilakukan Probity Audit hanya berdasarkan perintah atasan serta penilian peta risiko yang telah dimiliki masing-masing OPD yang dinilai dalam kegiatan berbeda sehingga hal tersebut yang kami gunakan dalam penentuan obyek auditan yang harus segera dilakukan 
audit. Untuk teknisnya kita mengacu pada Standar Audit Intern Pemerintah Indonesia (SAIPI) dan Pedoman Probity Audit BPKP dimana kita hanya menyesuaikan dari pedoman yang sudah ada dengan dengan kondisi tahapan yang akan kita lakukan Probity audit".

Selain itu juga kegiatan Probity Audit yang telah dilakukan oleh Inspektorat Kota Mojokerto pada tahapan pelaksanaan masih sebatas salah satu tahapan dari proses pengadaan barang dan jasa saja sehingga belum sepenuhnya dikatakan efektif dalam meminimalisir kecurangan dalam proses barang dan jasa. Permasalahan tersebut telah disadari oleh informan, yakni Sdr. Nuriman Zamroni Jouhar, SE bahwa adanya kendala yang ditemui oleh Inspektorat Kota Mojokerto dalam penerapan Probity audit, sebagaimana pernyataan berikut: "Dari Inspektorat Kota Mojokerto, seperti yang sudah kami sampaikan bahwa SDM merupakan salah satu kendala yang mempengaruhi cakupan Probity Audit yang kita bisa tindak lanjuti. Selain itu beban kerja Inspektorat untuk tidak hanya tertumpu pada kegiatan Audit khususnya barang dan jasa saja. Pada proses audit seringkali kita juga terkendala untuk tidak bisa menemui langsung Pihak yang terkait dalam proses pengadaan barang dan jasa karena kesesuaian waktu audit dengan kesiapan panitia pengadaan pada audit yang kita laksanakan. Hal lain yang juga menjadi kendala ialah OPD seringkali mengajukan permintaan audit hanya pada saat akan dilakukan pembayaran kepada penyedia".

Analisa atas Tahap Pemanfaatan atas Laporan Probity Audit yang dilakukan oleh Inspektorat Kota Mojokerto, untuk mengetahui efektifitas pemanfaatan hasil laporan Probity auditnya peneliti membandingkan antara "Ikhtisar Laporan Hasil Pengawasan Aparat Pengawasan Intern Pemerintah (APIP) Kota Mojokerto" pada tahun sebelumnya dengan "Ikhtisar Laporan Hasil Pengawasan Aparat Pengawasan Intern Pemerintah (APIP) Kota Mojokerto" pada tahun berikutnya. Dihasilkan penilaian bahwa tingkat pelaksanaan Probity Audit yang dilakukan oleh Inspektorat Kota Mojokerto sejauh ini bisa dikatakan efektif dilihat tidak adanya temuan serupa pada paket pekerjaan pengadaan yang serupa dengan tahun berikutnya. Pernyataan tersebut memperlihatkan bahwa rekomendasi terhadap temuan yang didapati oleh Auditor Inspektorat Kota Mojokerto pada kegiatan Probity Audit telah ditindak lanjuti oleh Obyek Pemeriksaannya, sehingga bermanfaat untuk meminimalisir penyimpangan serta akuntabilitas dana sektor publik dapat tercapai. Semua itu tidak lepas dari upaya Inspektorat Kota Mojokerto dalam memantau hasil temuannya sebagaimana yang disampaikan oleh Sdr. Drs. Leo Haposan, M.Si. pada tanggal 21 Mei 2021 bahwa: "Dalam melakukan pemantauan masing-masing tim yang telah melakukan probity audit, berkomunikasi dengan bagian sekretariat yang mengurusi tindak lanjut yang ada inspektorat untuk melihat kondisi rekomendasi yang kita keluarkan apakah telah ditindaklanjuti oleh auditan atau belum. Jika belum kita ingatkan untuk segera ditindaklanjuti sampai dengan batas akhir tindak lanjut, jika tetap tidak ditindaklanjuti akan kita teruskan ke Aparat Penegak Hukum (APH)".

\section{Efektifitas Probity Audit dalam Rangka Akuntabilitas Pengelolaan Dana Sektor Publik}

Berkaitan terhadap pelaksanaan pengadaan barang/jasa, "probity" juga dapat disebut sebagai "good process" yakni proses pelaksanaan pengadaan barang/jasa yang diterapkan berdasarkan prinsipprinsip penerapan integritas, fakta, serta kejujuran guna melaksanakan ketentuan hukum yang telah ditetapkan. Dimana artinya "probity audit" juga dapat dikatakan sebagai bagian dari penilaian (independen) guna menjamin bahwa proses pengadaan barang/jasa sudah diterapkan dengan cara yang konsisten berdasarkan pada ketentuan prinsip penegakan integritas, fakta, serta kejujuran dan juga berdasarkan pada ketentuan peraturan undang-undang yang berlaku dan ditujukan untuk menambah tingkat akuntabilitas atas penggunaan dana sektor publik (BPKP, 2012).

Untuk melihat semangat dari Auditor Inspektorat Kota Mojokerto maupun Organisasi Pemerintah Daerah (OPD) atas terwujudnya Akuntabilitas Dana Sektor Publik atas Probity Audit Barang dan Jasa, diberikan pertanyaan terkait efektifitas Probity Audit meminimalisir penyimpang yang terdapat pada proses pelaksanaan pengadaan barang dan jasa pernerintah. Kemudian hal ini diterangkan oleh Sdri. Rr. Intan Ari Budi Astuti, ST. MT pada tanggal 21 Mei 2021:

"Dari pengertiannya Probity adalah kejujuran, sehingga menurut kami probity ini dapat meminimalisir penyimpangan karena adanya keinginan/kejujuran dari auditan untuk diperiksa khususnya dalam pengadaan barang dan jasanya agar efektif dan efisien. Dari pengertiannya Probity adalah kejujuran, sehingga menurut kami probity ini dapat meminimalisir penyimpangan karena adanya keinginan/kejujuran dari auditan untuk diperiksa khususnya dalam pengadaan barang dan jasanya agar efektif dan efisien". 
Lebih lanjut ditambahkan pula oleh Sdr. Nuriman Zamroni Jouhar, SE dampak Probity Audit Barang dan Jasa oleh Inspektorat Kota Mojokerto: "Kami kira Probity Audit ini sangat positif karena kita bisa mencegah pemborosan anggaran akibat belanja yang dikeluarkan untuk pengadaan barang dan jasa akibat pengadaan barang dan jasa yang tidak akuntabel, selain itu atas penyelesaian waktu pekerjaan juga bisa kita cegah untuk keterlambatannya sehingga pengadaan barang dan jasa bisa termanfaatkan tepat waktu. Terkait potensi penyimpangan pada Pengadaan Barang dan Jasa yang berdampak pada praktek Korupsi, Kolusi dan Nepotisme (KKN) bisa kita minimalisir yang berdampak pada reputasi Pemerintahan Kota Mojokerto. Oleh karena itu kami kira Probity Audit ini sangat efektif dan efesien untuk akuntabilitas dana pada sektor publik".

Sehingga kesimpulannya yaitu proses pelaksanaan Probity Audit yang telah diterapkan oleh Inspektorat Kota Mojokerto, sudah mendapatkan animo yang baik dari OPD-OPD yang berada dalam pengawasannya. Hal tersebut karena adanya keinginan dari Organisasi Pemerintah Daerah agar akuntabilitas pengadaan barang dan jasa yang dilakukannya bisa tepat pada sasaran serta efisien. Sehingga tujuan dari pengadaan barang dan jasa dapat secara maksimal bisa dirasakan kegunaannya oleh anggota masyarakat serta berpengaruh pada penilaian yang baik pula kepada tata Kelola yang diselenggarakan oleh Pemerintah Kota Mojokerto.

Namun akuntabilitas dana sektor publik tentunya tidak mudah untuk dicapai tanpa adanya dukungan maupun kesiapan dari para pemangku kepentingan khususnya Inspektorat Kota Mojokerto. Oleh karena itu ditanyakan terkait kesiapan para APIP Inspektorat Kota Mojokerto atas terwujudnya Probity Audit dalam rangka akuntabilitas dana sektor publik. Menjawab hal tersebut Sdr. Drs. Leo Haposan, M.Si. yang menerangkan bahwa: "Karena merupakan tupoksi Inspektorat Kota Mojokerto untuk melalukan audit Barang dan Jasa, siap atau tidak kita harus siap. Walaupun jika dilihat dari segi SDM belum seluruh Auditor memiliki sertifikasi pengadaan Barang dan Jasa sebagaimana yang diharuskan dalam pedoman probity audit".

Lebih lanjut ditambahkan pula oleh Sdri. Rr. Intan Ari Budi Astuti, ST. MT.atas pemahaman auditor Inspektorat Kota Mojokerto atas Probity Audit Barang dan Jasa: "Kami kira sudah semua auditor Inspektorat Kota Mojokerto pemahaman atas Probity Audit karena seringkali semua auditor telah diikutkan Bimbingan Teknis (BIMTEK) terkait pengadaan barang dan Jasa, namun untuk sertifikasi pengadaan barang dan jasanya yang masih belum semua Auditor memilikinya", dan tidak kalah pentingnya adanya Komitmen dari pihak Pimpinan dalam memberikan dukungannya terhadap pelaksanaan Probity Audit dalam rangka meningkatkan Akuntabilitas Sektor Publik. Sdr. Drs. Leo Haposan, M.Si. menerangkan: "Pemimpinan kami kira sangat mendukung atas pelaksanaan Probity Audit ini, terlihat dari anggaran yang selalu disediakan khusus untuk peningkatan kapabilitas APIP, tujuannya agar Auditor di Inspektorat Kota Mojokerto terus mendapatkan ilmu pengatahuan yang mendukung tupoksi pengawasan Inspektorat Kota Mojokerto".

Berdasarkan hasil wawancara diatas, disimpulkan telah terdapat kemauan dan kesadaran yang tinggi dari sisi Auditor Inspektorat Kota Mojokerto maupun Organisasi Pemerintah Daerah (OPD) atas manfaat kegiatan Probity Audit Barang dan Jasa. Hal itu dikarenakan Probity Audit bisa mengurangi tingkat terjadinya fraud pada waktu proses pelaksanaan pengadaan barang dan jasa yang sedang berlangsung sehingga dirasa sangat efektif dan efisien dalam terwujudnya Akuntabilitas Dana Sektor Publik. Namun tetap disadari bahwa masih terdapat adanya keterbatasan-keterbatasan yang di miliki Inspektorat Kota Mojokerto. Probity Audit dilakukan pada saat periode proses pelaksanaan pengadaan barang dan jasa sedang berlangsung, yang artinya dalam pelaksanaanya membutuhkan waktu serta perencanaan yang khusus. Sehingga, diperlukan adanya komitmen oleh pihak pimpinan dalam memberikan dukungannya terhadap pelaksanaan Probity Audit atas pengadaan barang dan jasa tersebut, yang dapat berupa pembentukan peraturan serta pembentukan kebijakan khusus, selain itu juga dengan cara meningkatan kualitas dan jumlah dari SDM.

\section{Implikasi Penelitian}

Berlandaskan pada hasil analisa penelitian serta metode yang telah diterapkan menemukan hasil mengenai tata cara pelaksanaan Probity Audit atas pengadaan barang dan jasa yang telah dilaksanakan oleh Inspektorat Kota Mojokerto. Peran Inspektorat sebagai Pengawas Intern Daerah telah memberikan dampak yang cukup baik akan Akuntanbilitas Dana Sektor Publik di Lingkungan Pemerintahan Kota Mojokerto, melihat tidak ada lagi fenomena kasus khususnya pengadaan barang dan jasa, yang sampai 
ditangani oleh Aparat Penegak Hukum semenjak mulai efektif diterapkannya Probity Audit atas Pengadaan Barang dan Jasa pada tahun 2018 oleh Inspektorat Kota Mojokerto.

\section{Keterbatasan Penelitian}

Ketika melakukan penelitian ini, peneliti tidak lepas dari adanya keterbatasan atas penyajian hasil penelitian ini. Beberapa hal yang menjadi keterbatasan penelitian salah satunya terkait "triangulasi sumber data dan triangulasi teknik". Pada pelaksanaan triangulasi sumber data hanya berdasarkan datadata yang bisa didapatkan oleh peneliti yang berkaitan terhadap pelaksanaan Probity Audit dan disajikan oleh obyek penelitian. Sehingga mempengaruhi dalam triangulasi teknik, peneliti tidak bisa melakukan pengamatan/observasi serta mendapatkan pendapat dari auditee secara keseluruhan terhadap semua tahapan dari Probity Audit yang dilakukan oleh Inspektorat kota Mojokerto serta adanya keterbatasan waktu yang dimiliki peneliti untuk menyelesaian penelitian ini. Kemudian juga terdapat batasan dari pihak peneliti yang hanya melakukan penelitian di Inspektorat Kota Mojokerto dan peran auditee dari Inspektorat Kota Mojokerto untuk mendapatkan gambarkan lebih atas pelaksanaan Probity Audit pengadaan barang dan jasa yang dilakukan oleh Inspektorat Kota Mojokerto.

\section{KESIMPULAN}

Kesimpulan yang bisa dibentuk berlandaskan pada penelitian mengenai "Evaluasi Pelaksanaan Probity Audit atas Pengadaan Barang dan Jasa yang Dilakukan Inspektorat Kota Mojokerto" dan juga menilai efektivitas dari Probity Audit dalam rangka pengadaan barang dan jasa guna meningkatkan akuntabilitas dari penggunaan dana sektor publik, bisa disimpulkan seperti di bawah ini:

1. Pelaksanaan Probity Audit atas pengadaan Barang dan Jasa yang dilaksanakan oleh Inspektorat Kota Mojokerto sejauh ini dipandang masih memerlukan adanya sejumlah perbaikan dilihat dari penilaian pada tiga tahap pada pelaksanaan Probity Audit yang dilakukan yakni Perencanaan, Pelaksanaan dan Pemanfataan atas Laporan menunjukkan bahwa Inspektorat Kota Mojokerto pada tahap perencanaan telah merencakan adanya kegiatan Probity Audit pada Program Kerja Pengawasan Tahunan (PKPT), namun masih tidak menyeluruh. Dimana Inspektorat Kota Mojokerto dalam melaksanakan kegiatan Probity Audit atas pengadaan barang dan jasanya hingga kini masih belum memiliki kebijakan khusus yang mengatur pelaksanaan Probity Audit di Lingkungan Pemerintahan Kota Mojokerto sehingga pada implentasinya hanya merujuk pada Pedoman Probity yang dikeluarkan oleh BPKP sehingga belum sepenuhnya dikatakan efektif dalam meminimalisir kecurangan dalam proses barang dan jasa. Tahap Pemanfaatan atas Laporan yang dilakukan oleh Inspektorat Kota Mojokerto sejauh ini bisa dikatakan cukup efektif dilihat dari tidak adanya temuan serupa pada paket pekerjaan pengadaan yang serupa terhadap periode selanjutnya. Pernyataan tersebut memperlihatkan bahwa rekomendasi terhadap hasil yang didapatkan oleh Auditor Inspektorat Kota Mojokerto pada kegiatan Probity Audit telah ditindak lanjuti oleh Obyek Pemeriksaannya.

2. Penilaian efektifitas dari penerapan Probity Audit atas pengadaan barang dan jasa dinilai sangat efektif guna meningkatkan Akuntabilitas Pengelolaan Dana Sektor Publik dilihat dari kemauan dan kesadaran yang tinggi dari sisi Auditor Inspektorat Kota Mojokerto maupun Organisasi Pemerintah Daerah (OPD) atas manfaat yang diberikan dari kegiatan Probity Audit Barang dan Jasa selama ini.

\section{SARAN}

Berlandaskan temuan dari pembahasan di atas, sehingga peneliti juga turut menyajikan saran praktis kepada pihak instansi maupun saran teoritis kepada pihak peneliti bagi pengembangan penelitian selanjutnya, yaitu antara lain:

\section{Saran Praktis:}

1. Agar membuat kebijakan khusus mengenai pelaksanaan Probity Audit atas pengadaan barang dan jasa guna dijadikan acuan yang rinci sesuai kondisi di Lingkungan Pemerintahan.

2. Merencanakan dan melaksanakan kegiatan Probity Audit secara lebih komprehensif mulai tahap perencanaan, pemilihan pemenang, pelaksanaan dan pemanfaatan. Sehingga dapat meminimalisir segala bentuk fraud yang bisa saja muncul ketika dilakukan kegiatan pengadaan barang dan jasa yang diharapkan dapat berkurang. 
3. Meningkatkan pengetahuan dan kompetensi seluruh pegawai khususnya auditor atas pengadaan barang dan jasa dengan mengikuti diklat maupun bimbingan teknis lainnya. Serta mengikuti sertifikasi keahlian Pengadaan barang dan jasa, agar memenuhi spesifikasi standar yang diatur pada pedoman probity audit.

4. Melakukan sinergitas dan koordinasi dengan Organisasi Pemerintah Daerah (OPD). Hal ini disebabkan jangkauan sumber daya yang dimiliki dengan obyek pengawasan yang tidak sebanding sehingga kegiatan Probity Audit ini bisa mencakup kegiatan pengadaan barang dan jasa yang benar-benar efektif serta dapat berpengaruh bagi masyarakat luas.

5. Meningkatkan integritas dan komitmen pegawai khususnya pimpinan atas pentingnya kegiatan Probity Audit ini untuk menjaga akuntabilitas pengelolaan dana sektor publik.

\section{Saran Teoritis:}

1. Peneliti juga menyarankan bagi penelitian berikutnya supaya menerapkan bentuk penelitian yang lebih fokus kepada teknis pelaksaanan Probity Audit yang telah diterapkan oleh Inspektorat Kota Mojokerto, agar bisa untuk lebih mengetahui bagaimana tingkat kepatutan dari pelaksanaan Probity Audit yang telah diterapkan berdasarkan pada Pedoman Probity audit. Sehingga dapat saling mendukung dan diperbandingkan dengan temuan dari penelitian ini.

\section{REFERENSI}

Alzeban, A., \& Sawan, N. (2013). The Role of Internal Audit Function in The Public Sector Context in Saudi Arabia. African Journal of Business Management, Vol. 7 (No. 6), 443-454.

Arsyad, M., Suriadi, L. O., \& Anam, S. (2016). Analisis Pengadaan Barang dan Jasa Secara Elektronik (E-Procurement) Pada LPSE Kota Kendari Jurnal Ekonomi UHO, Vol. 1 (No. 1), 1-11.

BPK RI. (2017). Laporan Akuntabilitas Kinerja Tahun 2017. Jakarta: Badan Pemeriksa Keuangan Republik Indonesia. Diambil dari:

http://www.bpk.go.id/assets/files/storage/2018/05/file storage 1527140057.pdf

BPKP. (2012). Peraturan Kepala Badan Pengawasan Keuangan dan Pembangunan Nomor: Per362/K/04/2012 Tentang Pedoman Probity Audit Pengadaan Barang/Jasa Pemerintah Bagi Aparat Pengawasan Intern Pemerintah (APIP). Jakarta: Badan Pengawasan Keuangan dan Pembangunan. Diambil dari http://www.bpkp.go.id/uu/filedownload/8/105/2424.bpkp

Darwanis, Y. (2016). Pengendalian Intern Terhadap Good Governance Dan Dampaknya Pada Kualitas Laporan Keuangan (Studi Pada SKPA Pemerintah Aceh). Jurnal Administrasi Akuntansi: Program Pascasarjana Unsyiah, Vol. 5 (No. 2), 100-115.

Detkova, P., Podkolzina, E., \& Tkachenko, A. (2018). Corruption, Centralization and Competition: Evidence from Russian Public Procurement. International Journal of Public Administration Vol. 41 (No. 5-6), 414-434.

Diawati, M. (2017). Analisis Penerapan Probity Audit Pengadaan Barang dan Jasa (Studi pada Inspektorat Kabupaten Sleman). Accounting and Business Information Systems Journal, Vol. 5 (No. 4), 1-20.

Faisal, N. I., Morasa, J., \& Mawikere, L. M. (2017). Analisis Sistem Pengadaan Barang dan Jasa (Penunjung Langsung) Pada di Dinas Pekerjaan Umum dan Penataan Ruang Kota Manado. Going Concern: Jurnal Riset Akuntansi, Vol. 12 (No. 2), 1122-1132.

Hariyanto, I. (2020). 70\% Kasus Korupsi Terkait Barang dan Jasa, KPK Minta e-Katalog Dimaksimalkan. detik.com. Diakses 25 April 2021. Diambil dari: https://news.detik.com/berita/d-5147396/70-kasus-korupsi-terkait-barang-dan-jasa-kpkminta-e-katalog-dimaksimalkan

Jitmau, F., Kalangi, L., \& Lambey, L. (2017). Pengaruh Akuntabilitas, Transparansi dan Fungsi Pemeriksaan Intern Terhadap Kinerja Pemerintah Daerah (Studi Empiris Di Kabupaten Sorong). Jurnal Riset Akuntansi dan Auditing "Goodwill", Vol. 8 (No. 1), 276-285.

Kahn, R. L., Wolfe, D. M., Quinn, R. P., Snoek, J. D., \& Rosenthal, R. A. (1964). Organizational Stress: Studies in Role Conflict and Ambiguity. New York: John Wiley \& Sons. 
Mardiasmo. (2009). Otonomi dan Manjemen Keuangan Daerah. Yogyakarta: Andi.

Mulyono, P. E. (2017). Analisis Pelaksanaan Pengadaan Barang/Jasa secara Elektronik pada Pemerintah Kabupaten Gresik. Airlangga Development Journal, Vol. 1 (No. 1), 32-42.

Novitaningrum, B. D. (2014). Akuntabilitas dan Transparansi Pengadaan Barang dan Jasa Pemerintah Melalui Electronic Procurement (Best Practice di Pemerintah Kota Surabaya). Jurnal Kebijakan dan Manajemen Publik, Vol. 2 (No. 1), 200-210.

Nurrizkiana, B., Handayani, L., \& Widiastuty, E. (2017). Determinan Transparansi dan Akuntabilitas Pengelolaan Keuangan Daerah dan Implikasinya Terhadap Kepercayaan Public-Stakeholders. Jurnal Akuntansi dan Investasi, Vol. 18 (No. 1), 28-47.

Raharjo, S., \& Mahyuni, L. P. (2019). Faktor-Faktor Penentu Kualitas Audit Serta Pengaruh Kualitas Audit Terhadap Kepuasan Auditee Pada Pemerintah Daerah. Jurnal Manajemen Bisnis, Vol. 16 (No. 1), 115-125.

Rai, I. G. A. (2008). Audit Kinerja Pada Setor Publik: Konsep, Praktik, Studi Kasus. Jakarta: Salemba Empat.

Ramadhan, M. S., \& Arifin, J. (2019). Efektivitas Probity Audit dalam Mencegah Kecurangan Pengadaan Barang dan Jasa. Jurnal Akuntansi Multiparadigma, Vol. 10 (No. 3), 550-568. 